\title{
Evaluation of Normal and Nanolayer Composite Thermal Barrier Coatings in Fused Vanadate-Sulfate Salts at $1000^{\circ} \mathrm{C}$
}

\author{
Mohammadreza Daroonparvar, Muhamad Azizi Mat Yajid, Noordin Mohd. Yusof, \\ Hamid Reza Bakhsheshi-Rad, Mohammad Sakhawat Hussain, and Esah Hamzah
}

Department of Materials, Manufacturing and Industrial Engineering, Faculty of Mechanical Engineering,

Universiti Teknologi Malaysia, 81310 Johor Bahru, Johor, Malaysia

Correspondence should be addressed to Mohammadreza Daroonparvar; mr.daroonparvar@yahoo.com

Received 21 May 2013; Accepted 28 July 2013

Academic Editor: Rui Vilar

Copyright (C) 2013 Mohammadreza Daroonparvar et al. This is an open access article distributed under the Creative Commons Attribution License, which permits unrestricted use, distribution, and reproduction in any medium, provided the original work is properly cited.

\begin{abstract}
Hot corrosion behavior of yttria stabilized zirconia (YSZ), YSZ/normal $\mathrm{Al}_{2} \mathrm{O}_{3}$, and $\mathrm{YSZ} /$ nano- $\mathrm{Al}_{2} \mathrm{O}_{3}$ coatings was investigated in the presence of molten mixture of $\mathrm{Na}_{2} \mathrm{SO}_{4}+\mathrm{V}_{2} \mathrm{O}_{5}$ at $1000^{\circ} \mathrm{C}$. Microstructural characterization showed that the creation of hot corrosion products containing $\mathrm{YVO}_{4}$ crystals and monoclinic $\mathrm{ZrO}_{2}$ is primarily related to the reaction between $\mathrm{NaVO}_{3}$ and $\mathrm{Y}_{2} \mathrm{O}_{3}$ during hot corrosion. The lowest amount of hot corrosion products was observed in $\mathrm{YSZ}$ as an inner layer of $\mathrm{YSZ} /$ nano- $\mathrm{Al}_{2} \mathrm{O}_{3}$ coating. $\mathrm{Hence}$, it can be concluded that the presence of nanostructured $\mathrm{Al}_{2} \mathrm{O}_{3}$ layer over the conventional YSZ coating can considerably reduce the infiltration of molten corrosive salts into the YSZ layer during hot corrosion which is mainly related to the compactness of nanostructured alumina layer (including nanoregions) in comparison with normal alumina layer.
\end{abstract}

\section{Introduction}

Industrial gas turbine blades work at high temperatures. The efficiency and durability of gas turbine engines can be significantly modified by increasing their operating temperatures [1]. The efficiency and durability of turbine blades can be increased using high strength materials and protective coatings against high temperature oxidation and corrosion [2]. Thermal barrier coating (TBC) is usually used to reduce the substrate temperature [1].

TBC was first applied on aircraft engine parts in 1960. However, this coating had several problems such as structural instability of $\mathrm{ZrO}_{2}$ and poor bonding between the substrate and the ceramic coating (TBC) [2]. These problems were solved between 1970 and 1980 using

(1) yttria stabilized zirconia (YSZ) as a thermal barrier layer due to low thermal conductivity and high stability at elevated temperatures,

(2) metallic bond coat (MCrAlY) $(\mathrm{M}=\mathrm{Ni}, \mathrm{Co}$, or a mixture of these two) which was employed to improve the attachment between ceramic top coat and the substrate (Ni-based superalloy) and to provide protection for the alloy from additional oxidation [2].

On the other hand, YSZ coating is prone to hot corrosion when it is exposed to fused corrosive salts such as $\mathrm{V}_{2} \mathrm{O}_{5}$ and $\mathrm{Na}_{2} \mathrm{SO}_{4}$ at higher temperatures as these molten salts can diffuse into the YSZ layer and react easily with $\mathrm{Y}_{2} \mathrm{O}_{3}$ (stabilizer component of $\mathrm{ZrO}_{2}$ ). Therefore, the phase transformation of tetragonal zirconia to monoclinic zirconia followed by the formation of $\mathrm{YVO}_{4}$ crystals can occur during hot corrosion [3] as $\mathrm{YVO}_{4}$ crystals, and monoclinic zirconia as hot corrosion products will cause the separation of the ceramic layer from the bond coat $[4,5]$. Hence, YSZ coating as the main component of TBC system (base metal/MCrAlY/YSZ) must be maintained during service at elevated temperatures. It is interesting to note that $\mathrm{Al}_{2} \mathrm{O}_{3}$ is one of the strongest, cheapest, and hardest ceramics. Also this ceramic oxide is highly resistant to chemical changes in most applications. In addition, $\mathrm{Al}_{2} \mathrm{O}_{3}$ showed high resistance against corrosive and reductive atmospheres and liquid metals [6]. According to 
previous investigations [7], the characteristics of $\mathrm{ZrO}_{2}$ as the main component of TBC systems consist of

(1) high coefficient of thermal expansion (CTE),

(2) low thermal conductivity (TC).

On the other hand, the coefficient of thermal expansion of $\mathrm{Al}_{2} \mathrm{O}_{3}$ resembles CTE of $\mathrm{ZrO}_{2}$ at elevated temperatures. Thermal conductivity of $\mathrm{Al}_{2} \mathrm{O}_{3}$ can be significantly reduced at high temperatures as TC of $\mathrm{Al}_{2} \mathrm{O}_{3}$ resembles TC of $\mathrm{ZrO}_{2}$ in a TBC system during service $[7,8]$. In the meantime, the oxygen diffusivity from the crystalline structure of $\mathrm{Al}_{2} \mathrm{O}_{3}$ is lower in comparison to that of $\mathrm{ZrO}_{2}$ [9].

Heating conditions, along with the coating microstructure, have been cited in many reports as playing a pivotal role in providing TBC coatings with resistance against thermal shock, oxidation, and hot corrosion. Therefore, the efficiency and durability of TBC coatings can be manipulated by controlling the microstructure [10].

Many researchers have proved that resistance against the thermal shocks, oxidation, and hot corrosion depended principally on the coating structure (TBC) $[8,10]$.

Under this condition, it can be speculated that the nanosized $\mathrm{Al}_{2} \mathrm{O}_{3}$ layer with ultrafine grained structure over the YSZ coating can remarkably reduce the penetration of molten salts and oxygen into the YSZ layer, significantly preventing the formation of hot corrosion products in the YSZ layer. On the other hand, due primarily to the compact nature of the nanostructure, less voids and pores should appear in the nanostructured $\mathrm{Al}_{2} \mathrm{O}_{3}$ layer.

A substantial problem presents itself during the production of nanostructured ceramic coatings from the nanopowders. The problem is feeding the nano-powders into the plasma. Nanopowders adhere to the walls of the feeding system, making it extremely difficult to move them towards the plasma torch due to their high specific area and low mass. In order to overcome this problem, reconstitution of the nanoparticles into micrometer sized granules, a process known as granulation treatment, is necessary. The majority of investigators have demonstrated that the most favorable granule size is in the range of $10 \mu \mathrm{m}-110 \mu \mathrm{m}$ [11-14]. In order to obtain a dense nanoceramic coating by plasma spraying, granulated nanopowders must have excellent flow ability and high apparent density [14].

The main objectives of this paper are to produce a nanostructured ceramic coating from the granulated powders and to compare the hot corrosion resistance of $\mathrm{YSZ} /$ nano- $\mathrm{Al}_{2} \mathrm{O}_{3}$ coating with $\mathrm{YSZ} /$ normal $\mathrm{Al}_{2} \mathrm{O}_{3}$ and normal $\mathrm{YSZ}$ coatings in the presence of molten mixture of $45 \% \mathrm{Na}_{2} \mathrm{SO}_{4}+55 \% \mathrm{~V}_{2} \mathrm{O}_{5}$ at $1000^{\circ} \mathrm{C}$. It is anticipated that nanostructured $\mathrm{Al}_{2} \mathrm{O}_{3}$ coating could considerably lessen hot corrosion products in the YSZ as inner layer of $\mathrm{YSZ} /$ nano- $\mathrm{Al}_{2} \mathrm{O}_{3}$ coating.

\section{Experimental Procedures}

2.1. As-Received Materials. Nickel-based superalloy (Inconel 738 ) squares of $25 \times 25 \times 6 \mathrm{~mm}$ were employed as substrates. Amdry $962(\mathrm{Ni}-22 \mathrm{Cr}-10 \mathrm{Al}-1 \mathrm{Y},-106+52 \mu \mathrm{m})$, was used as bond coat. Metco $204 \mathrm{NS}-\mathrm{G}\left(\mathrm{ZrO}_{2}-8 \% \mathrm{Y}_{2} \mathrm{O}_{3},-106+11 \mu \mathrm{m}\right)$,
TABLE 1: The parameters of atmospheric plasma spraying (APS).

\begin{tabular}{lcccc}
\hline Parameter & NiCrAlY YSZ & $\begin{array}{c}\text { Normal } \\
\mathrm{Al}_{2} \mathrm{O}_{3}\end{array}$ & $\begin{array}{c}\text { Granulated } \\
\text { nano- } \mathrm{Al}_{2} \mathrm{O}_{3} \\
\text { powders }\end{array}$ \\
\hline $\begin{array}{l}\text { Current (A) } \\
\text { Voltage (V) }\end{array}$ & 50 & 550 & 500 & 500 \\
$\begin{array}{l}\text { Primary gas, Ar } \\
\text { (L/min) }\end{array}$ & 85 & 38 & 38 & 50 \\
$\begin{array}{l}\text { Secondary gas, } \mathrm{H}_{2} \\
\text { (L/min) }\end{array}$ & 15 & 17 & 17 & 85 \\
$\begin{array}{l}\text { Powder feed rate } \\
\text { (g/min) }\end{array}$ & 15 & 35 & 30 & 15 \\
Spray distance $(\mathrm{cm})$ & 15 & 7.5 & 9 & 25 \\
\hline
\end{tabular}

Amdry 6062 (normal $\alpha-\mathrm{Al}_{2} \mathrm{O}_{3}$ with high purity, $-80+15 \mu \mathrm{m}$ ), and Inframat LLC 0802 (nano- $\alpha-\mathrm{Al}_{2} \mathrm{O}_{3}$ with high purity, $80 \mathrm{~nm}$ ) were used as TBC or top coat.

2.2. Granulation Treatment of the Nano- $\mathrm{Al}_{2} \mathrm{O}_{3}$ Powders. Nano- $\mathrm{Al}_{2} \mathrm{O}_{3}$ powders with an average particle size nominally less than $80 \mathrm{~nm}$ and polyvinyl alcohol (PVA as a binder) were used as starting materials. In this method, $50 \mathrm{~g}$ of PVA was dissolved in $80 \mathrm{~mL}$ of distilled water at $200^{\circ} \mathrm{C}$ using a magnetic stirrer. At the same time, the nano- $\mathrm{Al}_{2} \mathrm{O}_{3}$ particles were dispersed in distilled water by using an ultrasonic machine for $30 \mathrm{~min}$ at $60^{\circ} \mathrm{C}$. Then, the dispersed nano- $\mathrm{Al}_{2} \mathrm{O}_{3}$ solution was added to the PVA solution with the aid of a magnetic stirrer at $250^{\circ} \mathrm{C}$ for $45 \mathrm{~min}$. The water from the solution was removed using a rotary evaporator in order to avoid phase segregation [12].

These granulated powders were dried using a normal electric furnace at $200^{\circ} \mathrm{C}$ for $145 \mathrm{~min}$. As mentioned previously, the required particle size for atmospheric plasma spraying was approximately $100 \mu \mathrm{m}$ [14]. Hence, these agglomerated powders were sieved through $150 \mu \mathrm{m}, 100 \mu \mathrm{m}$, and $50 \mu \mathrm{m}$ meshes in order to obtain an adequate shape and suitable size for plasma spraying. The final particle size of the granulated nano- $\mathrm{Al}_{2} \mathrm{O}_{3}$ powders used for atmospheric plasma spraying was about $100 \mu \mathrm{m}$.

2.3. Air Plasma Sprayed Coatings. In this research, at first, $\mathrm{NiCrAlY}$ coating was sprayed on the substrates (Inconel 738) with a thickness of $180 \pm 20 \mu \mathrm{m}$ and followed by three types of ceramic top coatings which were deposited on the NiCrAlY layer using air plasma spray (APS) method. The characteristics of the top coatings are as follows.

(a) Normal YSZ layer with a thickness $(t)$ of $380 \pm 20 \mu \mathrm{m}$.

(b) Layer composite of YSZ $(t=260 \pm 20 \mu \mathrm{m}) /$ normal $\mathrm{Al}_{2} \mathrm{O}_{3}(t=80 \pm 20 \mu \mathrm{m})$ coating.

(c) Layer composite of YSZ $(t=240 \pm 20 \mu \mathrm{m}) /$ nano$\mathrm{Al}_{2} \mathrm{O}_{3}(t=100 \pm 20 \mu \mathrm{m})$ coating.

The APS method was performed using a Sulzer-Metco $3 \mathrm{MB}$ plasma spray system. Table 1 shows the parameters of APS method. 


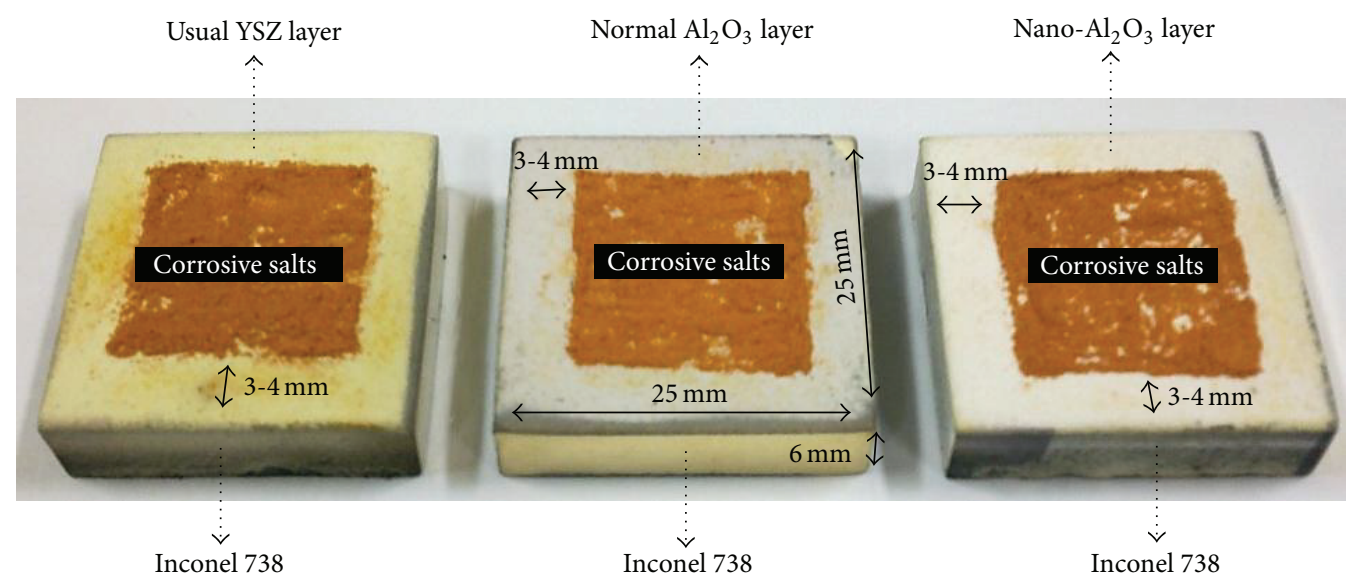

FIgURE 1: Taking care to stay within 3-4 mm from the edge, the coating surface was covered by $30 \mathrm{mg} / \mathrm{cm}^{2}$ of powdery mixture, forming an even film of corrosive material (in order to prevent the effects of edge corrosion).

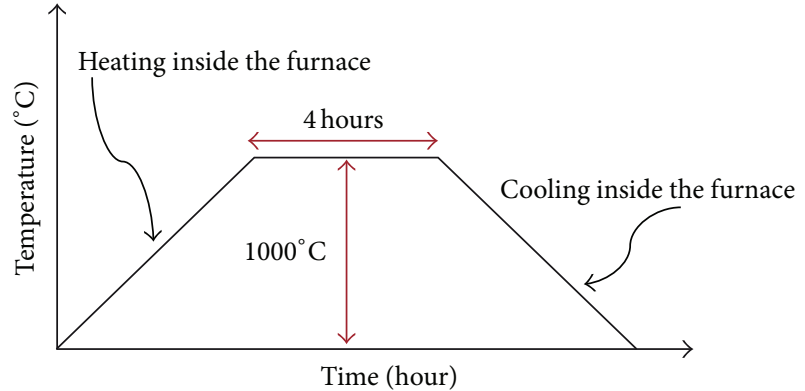

FIGURE 2: Schematic curve of hot corrosion cycles at $1000^{\circ} \mathrm{C}$.

2.4. Hot Corrosion Test at $1000^{\circ} \mathrm{C} . \mathrm{V}_{2} \mathrm{O}_{5}$ and $\mathrm{Na}_{2} \mathrm{SO}_{4}$ are principal corrosive compounds at hot corrosion process. Accordingly, a mixture of $55 \% \mathrm{~V}_{2} \mathrm{O}_{5}+45 \% \mathrm{Na}_{2} \mathrm{SO}_{4}$ powders of $99.99 \%$ purity was used as corrosive salt $[5,10,15]$. The physical specifications of each salt are presented in Table 2. Taking care to stay within 3-4 $\mathrm{mm}$ from the edge, the coating surface was covered by $30 \mathrm{mg} / \mathrm{cm}^{2}$ of powdery mixture, forming an even film of corrosive material (in order to prevent the effects of edge corrosion), as seen in Figure 1. The samples were then set in a normal electric furnace with an air atmosphere of $1000^{\circ} \mathrm{C}$ for $4 \mathrm{hr}$ and then cooled down until ambient temperature was reached inside the furnace (in order to prevent the thermal shocks), as shown in Figure 2. Also, the coatings were inspected after every $4 \mathrm{hr}$ of hot corrosion cycles $[10,16]$. If there were any cracks or separation in the coating edge, the hot corrosion test was stopped. The temperature of the hot corrosion test and the concentration of corrosive salts were, respectively, selected according to zirconia phase transformation, melting point of corrosive salts, and accomplishing a fast experiment.

2.5. Microstructural Characterization. The surface and the cross-section of the coatings before and after hot corrosion test were explored using field emission scanning electron microscopy (FESEM, Hitachi S-4160) and scanning electron microscopy (SEM, Japan, EM15) equipped with energy
TABLE 2: The physical specifications of corrosive salts.

\begin{tabular}{lccc}
\hline $\begin{array}{l}\text { Type of } \\
\text { corrosive salt }\end{array}$ & Melting point $\left({ }^{\circ} \mathrm{C}\right)$ & Density $\left(\mathrm{g} / \mathrm{cm}^{2}\right)$ & Purity (\%) \\
\hline $\mathrm{Na}_{2} \mathrm{SO}_{4}$ & 884 & 2.7 & 99.98 \\
$\mathrm{~V}_{2} \mathrm{O}_{5}$ & 690 & 3.3 & 99.99 \\
\hline
\end{tabular}

dispersive spectrometer (EDS). In order to determine the type of formed phases on the YSZ layer of TBCs after hot corrosion test, XRD was conducted (Siemens-D500) by using $\mathrm{Cu} \mathrm{K} \alpha$ line generated at $40 \mathrm{kV}$ and $35 \mathrm{~mA}$.

\section{Results and Discussion}

3.1. Nano- $\mathrm{Al}_{2} \mathrm{O}_{3}$ Powders after Granulation. Figure 3(a) shows the surface morphology of nano- $\mathrm{Al}_{2} \mathrm{O}_{3}$ powders after granulation. It can be observed that, after granulation, particle size has increased. It can be seen that there are several nano- $\mathrm{Al}_{2} \mathrm{O}_{3}$ grains (Figure $3(\mathrm{~b})$ ) in a granulated particle which is suitable for plasma spraying.

3.2. Microstructural Characterization of Coatings before Hot Corrosion Test. Figure 4 shows the cross-section of the assprayed coatings. It can be seen that all layers of the assprayed coatings have lamellar structure (Figures 4(a), 4(b), and $4(\mathrm{c}))$. This specification belongs to the air plasma sprayed coatings [1]. It can be observed that normal $\mathrm{Al}_{2} \mathrm{O}_{3}$ and YSZ layers have formed a normal-layer composite coating (Figure 4(a)), and also nano- $\mathrm{Al}_{2} \mathrm{O}_{3}$ and YSZ layers have formed a nanolayer composite coating (Figure 4(c)) on the bond coat. Figures 5 and 6 indicate the surface of the assprayed coatings at different magnifications. It can be said that nano- $\mathrm{Al}_{2} \mathrm{O}_{3}$ layer (Figures 5(a), 5(b), and 6(a)) has the lowest number of pinholes and microcracks compared to that of normal $\mathrm{Al}_{2} \mathrm{O}_{3}$ layer (Figures 5(c), 5(d), and 6(c)). On the other hand, the YSZ layer has more pinholes and micro-cracks (Figures 5(e), 5(f), and 6(b)). Figure 7 also shows that nanostructured $\mathrm{Al}_{2} \mathrm{O}_{3}$ layer has been made from ultrafine particles. It is expected that nano- $\mathrm{Al}_{2} \mathrm{O}_{3}$ layer over 


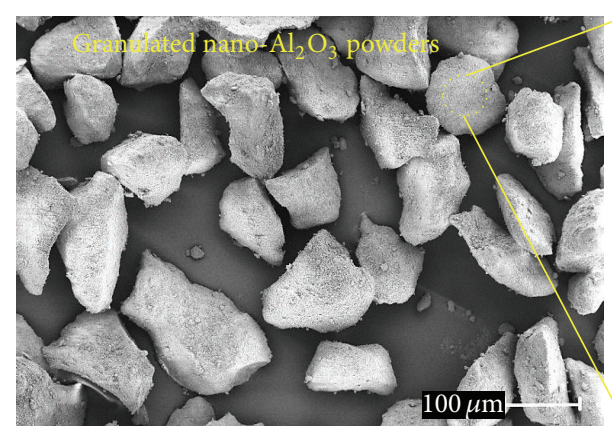

(a)

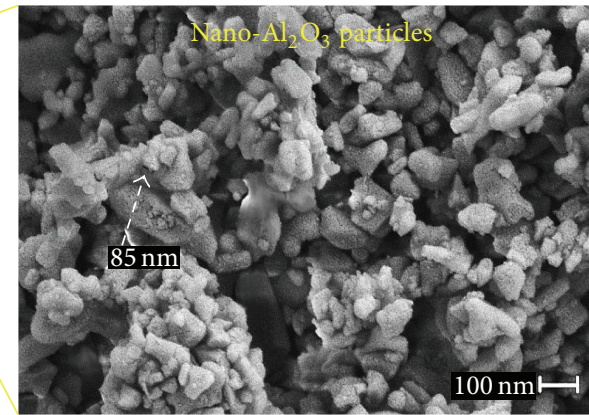

(b)

FIGURE 3: FESEM images of nano- $\mathrm{Al}_{2} \mathrm{O}_{3}$ powders after granulation with different magnifications (a) $\times 100$ and $(\mathrm{b}) \times 20.0 \mathrm{~K}$.

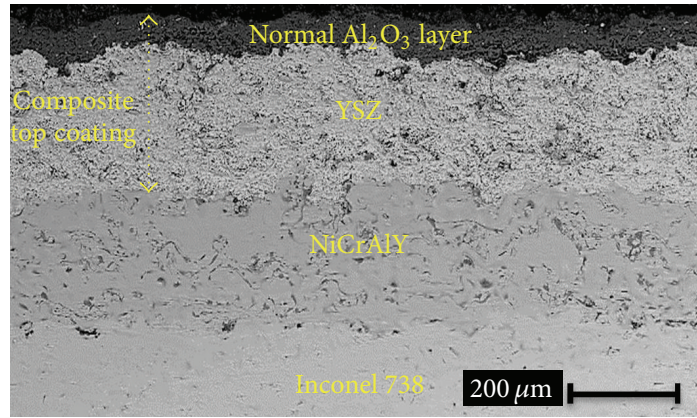

(a)

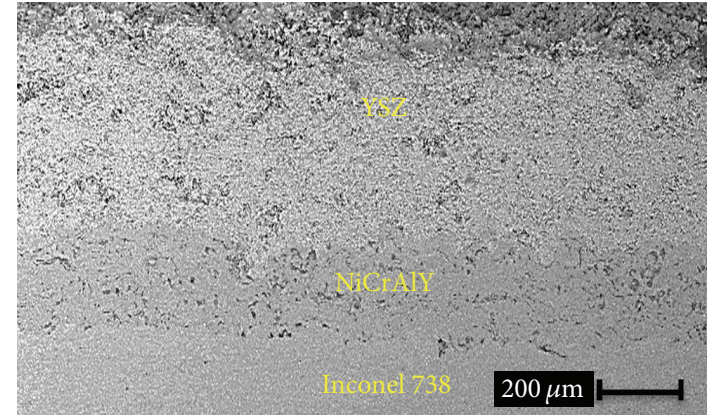

(b)

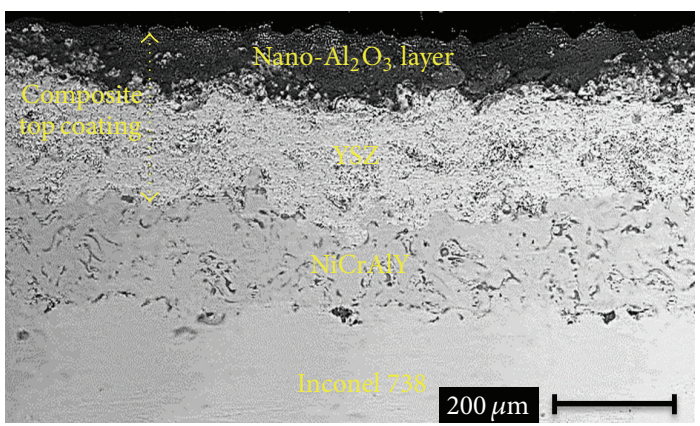

(c)

FIGURE 4: Cross-section of the as-sprayed coatings.

the YSZ layer could considerably reduce $\mathrm{O}_{2}$ diffusion and infiltration of corrosive molten salts into the YSZ layer at elevated temperatures. This phenomenon may be related to the compactness of the nanostructured $\mathrm{Al}_{2} \mathrm{O}_{3}$ layer (Figures 6(a) and 7(a)).

3.2.1. X-Ray Diffraction Analysis of Outer Surface of TBCs before Hot Corrosion Test. Figure 8 shows the XRD analysis of outer surface of TBCs after air plasma spraying. Figure 8(a) exhibits that the as-sprayed normal YSZ coating is mainly composed of tetragonal zirconia $(t)$ phase. It is observed that nano-(Figure $8(\mathrm{~b})$ ) and normal (Figure $8(\mathrm{c})$ ) $\mathrm{Al}_{2} \mathrm{O}_{3}$ coatings are mainly composed of $\alpha-\mathrm{Al}_{2} \mathrm{O}_{3}$ (rhombohedral) and $\gamma$ $\mathrm{Al}_{2} \mathrm{O}_{3}$ (cubic) phases after spraying.

3.3. Microstructural Characterization of Coatings after Hot Corrosion Test. Figure 9 shows the cross-section of the coatings after hot corrosion test at $1000^{\circ} \mathrm{C}$. Figures 9(a) and 9(b) clearly show a wide crack in YSZ coating (after $12 \mathrm{~h}$ or 3 cycles of hot corrosion test) which is a direct result of the formation of monoclinic $\mathrm{ZrO}_{2}$ and $\mathrm{YVO}_{4}$ large crystals. Although the spallation of normal $\mathrm{Al}_{2} \mathrm{O}_{3}$ layer of $\mathrm{YSZ} /$ normal $\mathrm{Al}_{2} \mathrm{O}_{3}$ coating occurred after $44 \mathrm{~h}$ (11 cycles of hot corrosion test), YSZ as inner layer was free of cracks or delamination (Figure 9(c)). Also, in $\mathrm{YSZ} /$ nano- $\mathrm{Al}_{2} \mathrm{O}_{3}$ coating, the spallation of nano$\mathrm{Al}_{2} \mathrm{O}_{3}$ layer was observed after $52 \mathrm{~h}$ of hot corrosion test (after 13 cycles of hot corrosion test), but cracking or delamination in YSZ as inner layer was not seen (Figure 9(d)). It is seen that the YSZ layer as the main component of TBC systems has been maintained in layered composite coatings compared to conventional YSZ coating after hot corrosion tests.

Figure 10 demonstrates XRD patterns obtained from the normal YSZ layer, YSZ as inner layer of YSZ/normal $\mathrm{Al}_{2} \mathrm{O}_{3}$ coating and $\mathrm{YSZ}$ as inner layer of $\mathrm{YSZ} /$ nano- $\mathrm{Al}_{2} \mathrm{O}_{3}$ coating after the hot corrosion test using the $45 \% \mathrm{Na}_{2} \mathrm{SO}_{4}+55 \% \mathrm{~V}_{2} \mathrm{O}_{5}$ 


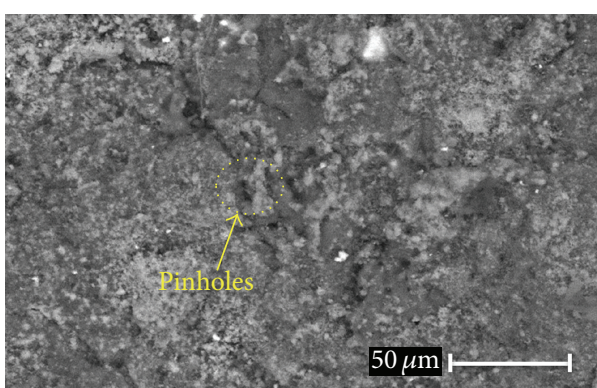

(a)

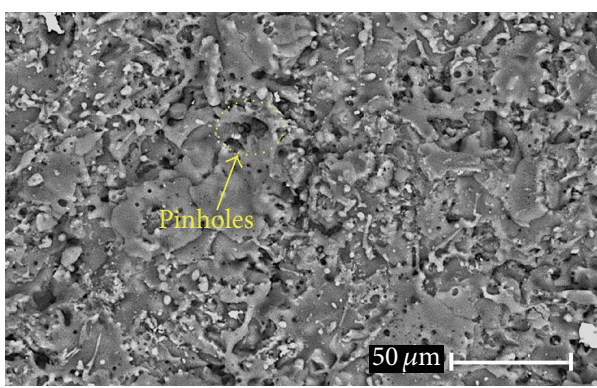

(c)

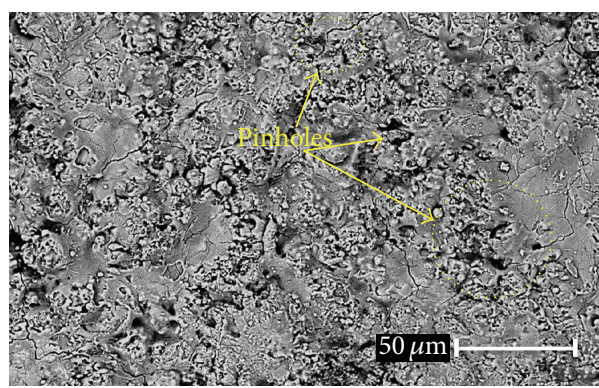

(e)

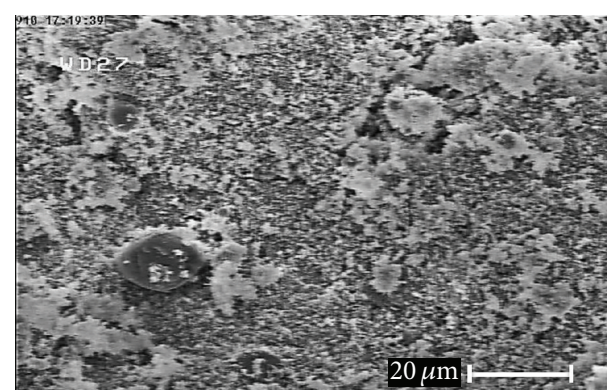

(b)

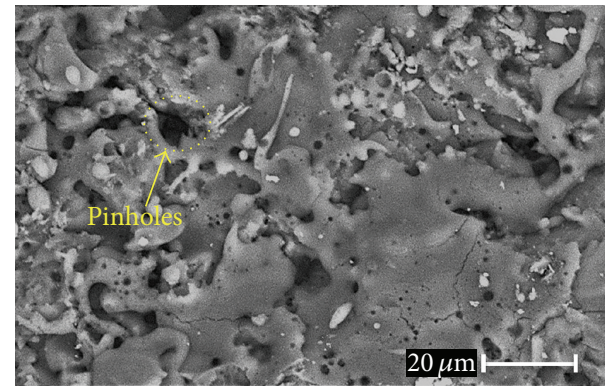

(d)

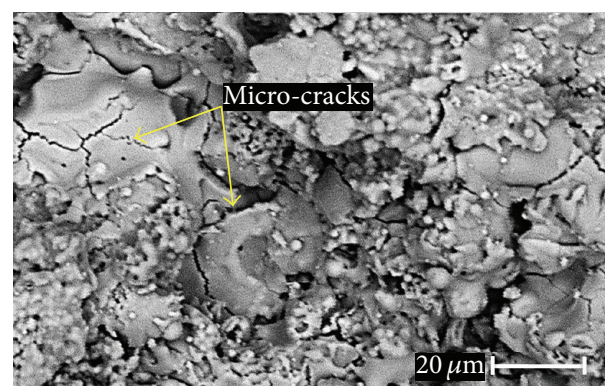

(f)

FIGURE 5: Surface morphology of the as-sprayed coatings: $(\mathrm{a}, \mathrm{b})$ nanostructured $\mathrm{Al}_{2} \mathrm{O}_{3}$ layer, $(\mathrm{c}, \mathrm{d})$ normal $\mathrm{Al}_{2} \mathrm{O}_{3}$ layer; and (e, f) normal YSZ layer.

salt mixture at $1000^{\circ} \mathrm{C}$. According to XRD patterns, the YSZ layer of coatings, as the main component of TBC system, contains not only tetragonal zirconia but also additional new phases which may be regarded as hot corrosion products; monoclinic zirconia and tetragonal $\mathrm{YVO}_{4}$ composition, are also present. As mentioned, $\mathrm{YVO}_{4}$ crystals and monoclinic zirconia as hot corrosion products were accompanied by a rapid local volume increase, finally causing the separation of the ceramic layer from the bond coat. Therefore, the formation and growth of hot corrosion products in YSZ layer are believed to be detrimental to the durability of TBC systems at elevated temperatures. So, they must be reduced in the YSZ layer.

As shown in Figure 10, the intensity peak of hot corrosion product phases in YSZ as inner layer of $\mathrm{YSZ} /$ nano- $\mathrm{Al}_{2} \mathrm{O}_{3}$ coating has been considerably reduced in comparison to normal YSZ coating and YSZ as inner layer of YSZ/normal $\mathrm{Al}_{2} \mathrm{O}_{3}$ coating after hot corrosion test.

It can be seen that the intensity peak of $\mathrm{YVO}_{4}$ crystals in normal YSZ coating is much higher compared to that of YSZ as inner layer of YSZ/nano- $\mathrm{Al}_{2} \mathrm{O}_{3}$ and $\mathrm{YSZ} /$ normal $\mathrm{Al}_{2} \mathrm{O}_{3}$ coatings, respectively. In other words, by measuring the surface areas covered by the hot corrosion products, for all three coatings, the hot corrosion resistance of TBCs can be qualitatively measured. As seen in Figure 11(a), the hot corrosion product of $\mathrm{YVO}_{4}$ covers almost the entire surface which may be attributed to the inhomogenously distributed microcracks and open pores inside the conventional YSZ layer (Figures 5(e), 5(f), and 6(b)); in Figure 11(c), an estimated $45 \%$ of the area is covered by $\mathrm{YVO}_{4}$, and, in Figure 11(e), this figure is reduced to about $20 \%$ of the surface area. In this regard, Figures 11 (a) and 11(b) were taken after three $4 \mathrm{~h}$ hot corrosion cycles, Figures $11(\mathrm{c})$ and 11(d) were taken after eleven $4 \mathrm{~h}$ hot corrosion cycles, and finally Figures 11(e) and 11(f) were taken after thirteen $4 \mathrm{~h}$ hot corrosion cycles. So, it can be seen that the nanostructured $\mathrm{Al}_{2} \mathrm{O}_{3}$ layer over the YSZ coating would significantly suppress the formation and growth of $\mathrm{YVO}_{4}$ crystals in YSZ layer which must be preserved (Figure $9(\mathrm{~d})$ ) during service.

The unstable phase of monoclinic zirconia expressed as a percentage is very important in hot corrosion process. 


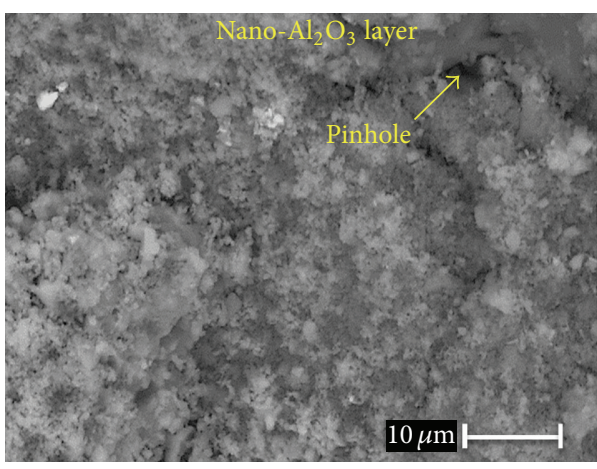

(a)

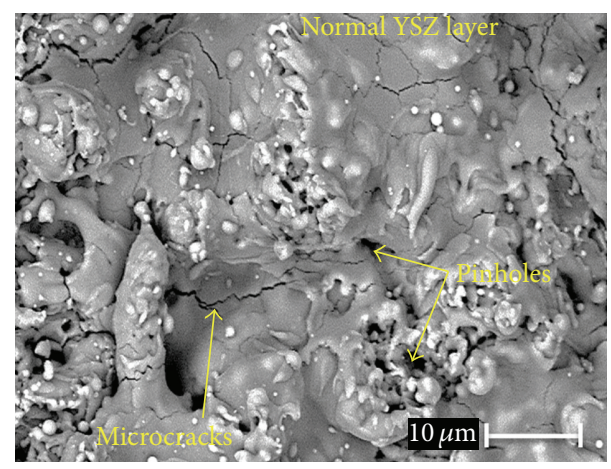

(b)

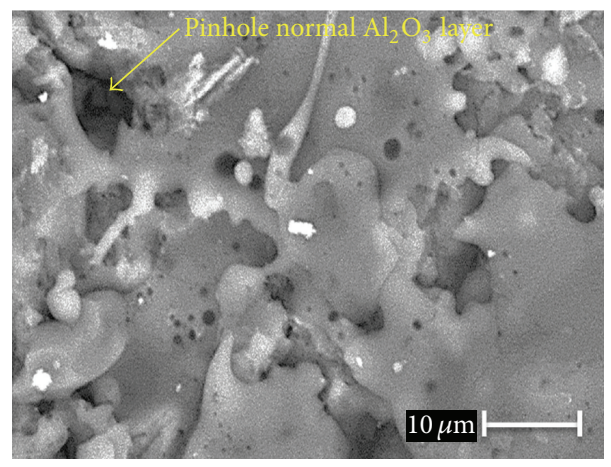

(c)

FIGURE 6: Surface morphology of the as-sprayed coatings with high magnification: (a) nanostructured $\mathrm{Al}_{2} \mathrm{O}_{3}$ layer, (b) normal YSZ layer, and (c) normal $\mathrm{Al}_{2} \mathrm{O}_{3}$ layer.

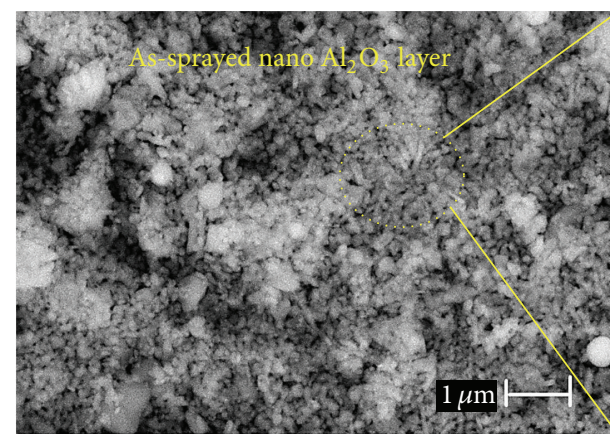

(a)

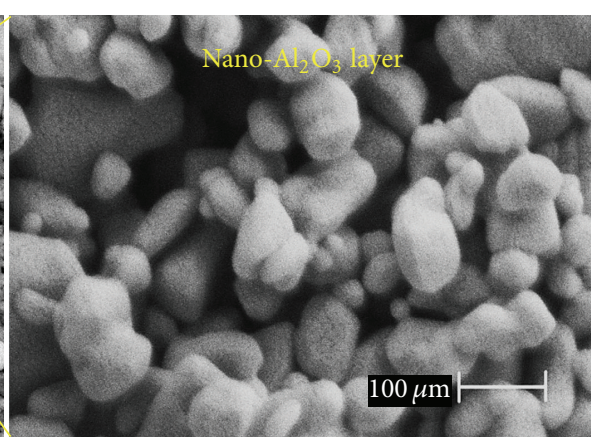

(b)

FIGURE 7: FESEM images of surface of the as-sprayed nanostructured $\mathrm{Al}_{2} \mathrm{O}_{3}$ layer made from ultrafine particles: (a) $\times 5.0 \mathrm{~K}$ and $(\mathrm{b}) \times 50.0 \mathrm{~K}$.

Equation (1) is applied in order to determine monoclinic phase volume fraction [10]:

$$
M \%=\frac{M_{1}+M_{2}}{M_{1}+M_{2}+T} * 100,
$$

where $T$ is the intensity peak of tetragonal zirconia at (101) plane, $M_{1}$ is the intensity peak of monoclinic zirconia at (111) plane, and $M_{2}$ is the intensity peak of monoclinic zirconia at (111) plane, in XRD plots (see Figure 10) after hot corrosion test. The percentage of monoclinic phase volume was derived using (1). For normal YSZ coating, YSZ as inner layer of $\mathrm{YSZ} /$ normal $\mathrm{Al}_{2} \mathrm{O}_{3}$ coating, and $\mathrm{YSZ}$ as inner layer of YSZ/nano- $\mathrm{Al}_{2} \mathrm{O}_{3}$ coating, this parameter was calculated to be $66 \%, 21 \%$, and $15 \%$, respectively. Clearly, normal YSZ in terms of the volume fraction of monoclinic zirconia is the greatest, while the least is that of YSZ layer in YSZ/nano$\mathrm{Al}_{2} \mathrm{O}_{3}$ coating.

The premature deterioration of conventional YSZ layer from the bond coat is primarily related to the more formation and propagation of hot corrosion products specifically $\mathrm{YVO}_{4}$ crystals in the normal YSZ coating during hot corrosion, as shown in Figures 10, 11(a), and 11(b).

As shown in Figure 11(a), porous and destroyed surface with many micro-cracks and needle-like crystals (as first hot corrosion product) can be seen on the surface of normal YSZ 


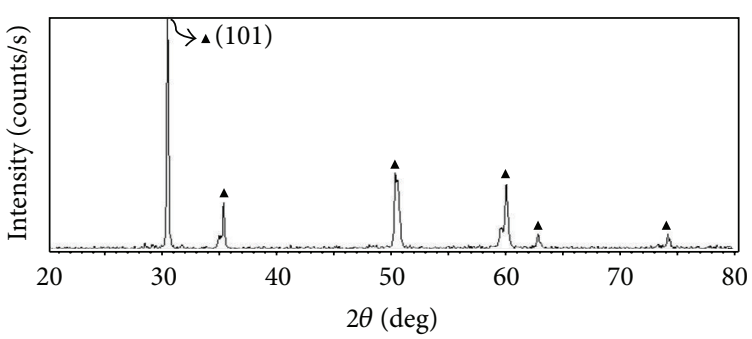

(a)

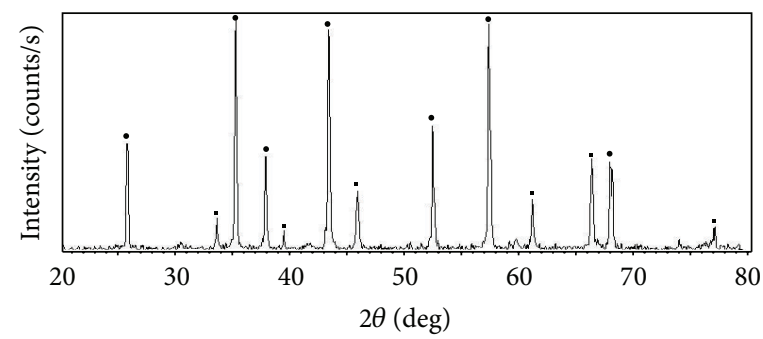

(b)

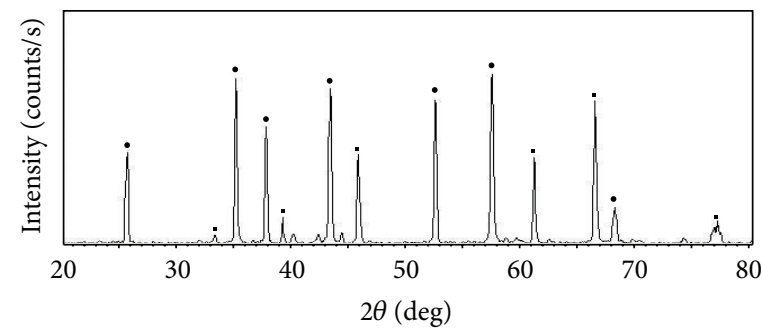

A $\mathrm{ZrO}_{2}$ tetragonal

- $\alpha-\mathrm{Al}_{2} \mathrm{O}_{3}$ (rhombohedral)

- $\gamma-\mathrm{Al}_{2} \mathrm{O}_{3}$ (cubic)

(c)

FIGURE 8: XRD patterns of (a) normal YSZ layer, (b) nano- $\mathrm{Al}_{2} \mathrm{O}_{3}$ coating, and (c) normal $\mathrm{Al}_{2} \mathrm{O}_{3}$ coating after air plasma spraying.

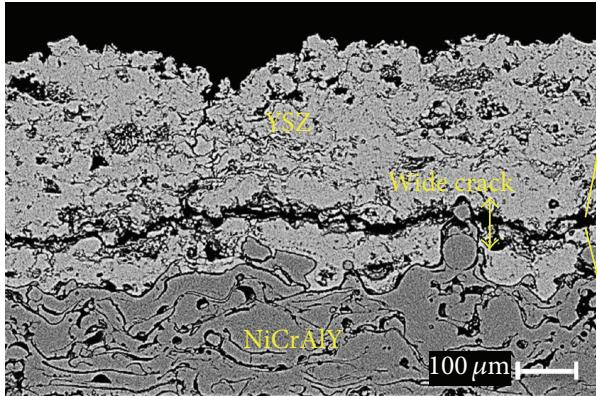

(a)

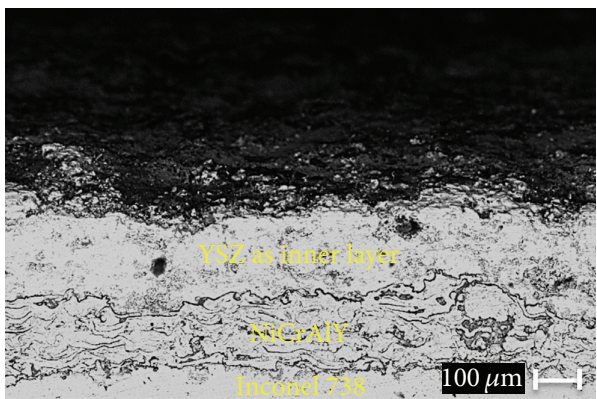

(c)

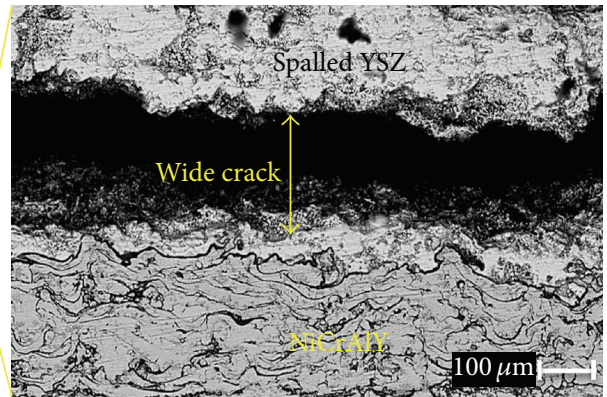

(b)

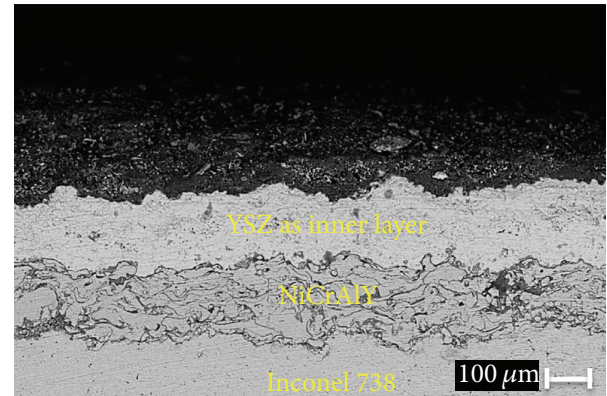

(d)

FIGURE 9: Cross-section of the coatings after hot corrosion testing at $1000^{\circ} \mathrm{C}$. (a, b) Conventional YSZ coating, (c) YSZ as inner layer of $\mathrm{YSZ} /$ normal $\mathrm{Al}_{2} \mathrm{O}_{3}$ coating, and (d) $\mathrm{YSZ}$ as inner layer of $\mathrm{YSZ} /$ nano- $\mathrm{Al}_{2} \mathrm{O}_{3}$ coating.

coating. $\mathrm{YVO}_{4}$ initially has a dendritic shape at the start of the hot corrosion process following the nucleation and growth mechanism; this shape changes to a rod/flat (Figure 11(a)) or needle- (Figure 11(b)) like shape as the hot corrosion process proceeds.
The normal alumina layer spalled at the interface of YSZ/normal $\mathrm{Al}_{2} \mathrm{O}_{3}$; hence, Figure 11(c) shows the surface of YSZ as inner layer of YSZ/normal $\mathrm{Al}_{2} \mathrm{O}_{3}$ coating after $44 \mathrm{~h}$ of hot corrosion test. Also, the nano- $\mathrm{Al}_{2} \mathrm{O}_{3}$ layer spalled at the interface of $\mathrm{YSZ} /$ nano- $\mathrm{Al}_{2} \mathrm{O}_{3}$ coating after $52 \mathrm{~h}$ of hot 


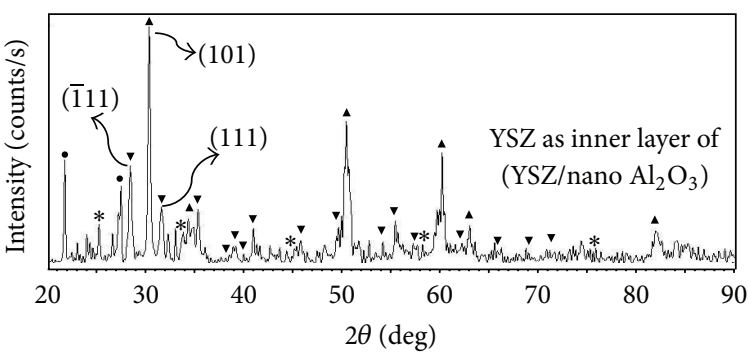

(a)

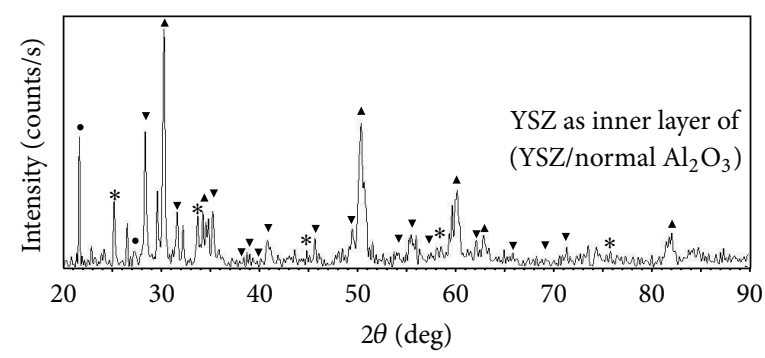

(b)

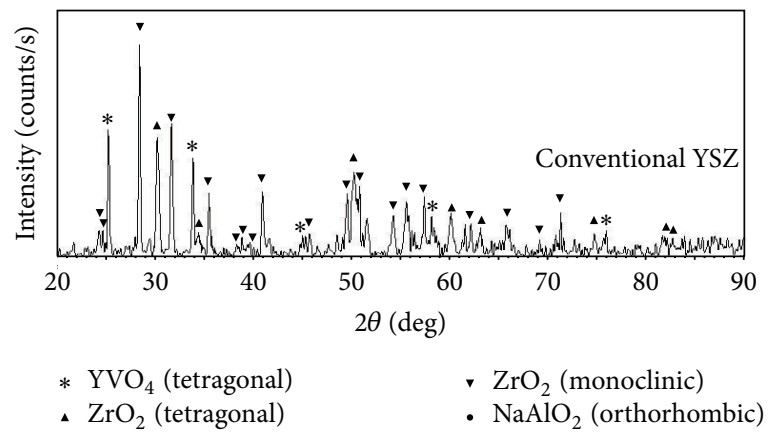

(c)

FIGURE 10: XRD patterns of (a) normal YSZ layer, (b) YSZ as inner layer of YSZ/normal $\mathrm{Al}_{2} \mathrm{O}_{3}$ coating, and (c) YSZ as inner layer of YSZ/nano$\mathrm{Al}_{2} \mathrm{O}_{3}$ coating after hot corrosion testing.

corrosion test; therefore Figure 11(e) indicates the surface of YSZ as inner layer of $\mathrm{YSZ} /$ nano- $\mathrm{Al}_{2} \mathrm{O}_{3}$ coating after hot corrosion test.

The detrimental crystals were $\mathrm{rod} /$ needle or flat shaped in usual YSZ with large size $(85 \mu \mathrm{m})$ and thicker $(2.5 \mu \mathrm{m})$ (Figures 11(b) and 12(a)), thin rod crystals $(1.5 \mu \mathrm{m})$ with medium size $(50 \mu \mathrm{m})$ in $\mathrm{YSZ} /$ normal $\mathrm{Al}_{2} \mathrm{O}_{3}$ coating (Figures $11(\mathrm{~d})$ and $12(\mathrm{~b}))$, and thinner rod crystals $(0.5 \mu \mathrm{m})$ with low number and small size $(10 \mu \mathrm{m})$ in $\mathrm{YSZ} /$ nano- $\mathrm{Al}_{2} \mathrm{O}_{3}$ coating (Figures 11(f) and 12(c)).

It is seen that the formation and propagation of rod/flator needle-shaped crystals are much less in $\mathrm{YSZ} /$ nano- $\mathrm{Al}_{2} \mathrm{O}_{3}$ coating. This is because nanostructured $\mathrm{Al}_{2} \mathrm{O}_{3}$ layer with less pinholes and micro-cracks $[17,18]$ can considerably prevent the infiltration of molten salts into the YSZ layer in comparison with normal $\mathrm{Al}_{2} \mathrm{O}_{3}$ and conventional YSZ coatings. In this regard, it can be said that nanostructured $\mathrm{Al}_{2} \mathrm{O}_{3}$ should have less pores and voids due to the compactness of the nanostructure (Figures 5(a), 6(a), and 7(a)).

Energy dispersive spectrometer (EDS) analysis (see Figure 13) demonstrated that the rod crystals were mainly composed of yttrium, vanadium, and oxygen. Also, XRD analysis identified these crystals as $\mathrm{YVO}_{4}$ (tetragonal) (Figure 10). This result is in agreement with previous investigations $[3,5]$. As mentioned earlier, exposing these porous areas to phase analysis demonstrates that tetragonal zirconia, in large amounts, had been transformed to monoclinic phase (as the second hot corrosion product) on the surface of the conventional YSZ top layer due to the depletion of yttria (as stabilizer component of zirconia). It can be said that a Lewis acid-base mechanism is driving the reactions between vanadium compounds and ceramic oxides. These ceramic oxides have a stronger basicity, and acid vanadium compounds react with them more readily. This can be explained since the basicity of yttrium oxide and zirconium dioxide follows the order: $\mathrm{Y}_{2} \mathrm{O}_{3}>\mathrm{ZrO}_{2}$, indicating that molten $\mathrm{NaVO}_{3}$ has the tendency to react with $\mathrm{Y}_{2} \mathrm{O}_{3}$ more easily [19].

On the whole, according to above results, it can be said that the nanostructured $\mathrm{Al}_{2} \mathrm{O}_{3}$ layer over the $\mathrm{YSZ}$ coating can act as a strong barrier for the diffusion of fused corrosive materials into the YSZ layer and would considerably lessen the hot corrosion products formation in the normal YSZ layer at elevated temperatures.

3.4. Hot Corrosion Mechanism of YSZ Coating at Elevated Temperatures. The hot corrosion behavior and failure mechanism of TBC in the present research consist of the following steps that are consistent with previous observations [20, 21].

At first, $\mathrm{V}_{2} \mathrm{O}_{5}$ (with melting point of $690^{\circ} \mathrm{C}$ ) will react with $\mathrm{Na}_{2} \mathrm{SO}_{4}$ (with melting point of $884^{\circ} \mathrm{C}$ ) during thermal exposure at elevated temperature $\left(1000^{\circ} \mathrm{C}\right)$, and then $\mathrm{NaVO}_{3}$ (with melting point of $610^{\circ} \mathrm{C}$ ) will be formed (Reaction (2)):

$$
\mathrm{V}_{2} \mathrm{O}_{5}(\mathrm{l})+\mathrm{Na}_{2} \mathrm{SO}_{4}(\mathrm{l}) \longrightarrow 2 \mathrm{NaVO}_{3}(\mathrm{l})+\mathrm{SO}_{3}(\mathrm{~g}) \uparrow
$$

$\mathrm{NaVO}_{3}$ will then react with the stabilizer component $\left(\mathrm{Y}_{2} \mathrm{O}_{3}\right)$ of tetragonal $\mathrm{ZrO}_{2}$ to form $\mathrm{YVO}_{4}$ crystals and monoclinic $\mathrm{ZrO}_{2}$ (Reaction (3)):

$$
\begin{aligned}
& \mathrm{ZrO}_{2}\left(\mathrm{Y}_{2} \mathrm{O}_{3}\right)(\mathrm{s})+2 \mathrm{NaVO}_{3}(\mathrm{l}) \\
& \quad \longrightarrow \mathrm{ZrO}_{2} \text { (monoclinic) (s) }+2 \mathrm{YVO}_{4}(\mathrm{~s})+\mathrm{Na}_{2} \mathrm{O}(\mathrm{l})
\end{aligned}
$$

It can be said that the monoclinic $\mathrm{ZrO}_{2}$ is as an unstable phase. This phase will be transformed to tetragonal 


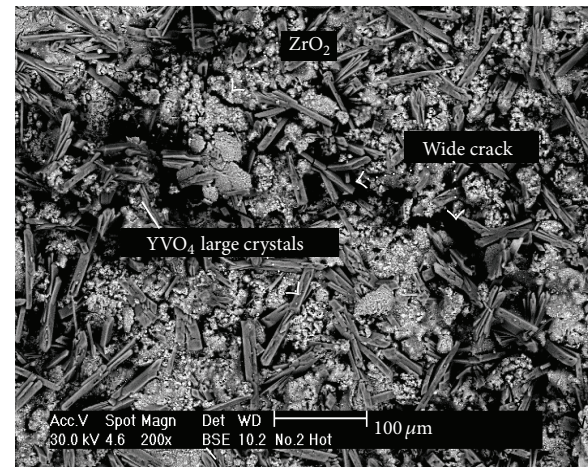

(a)

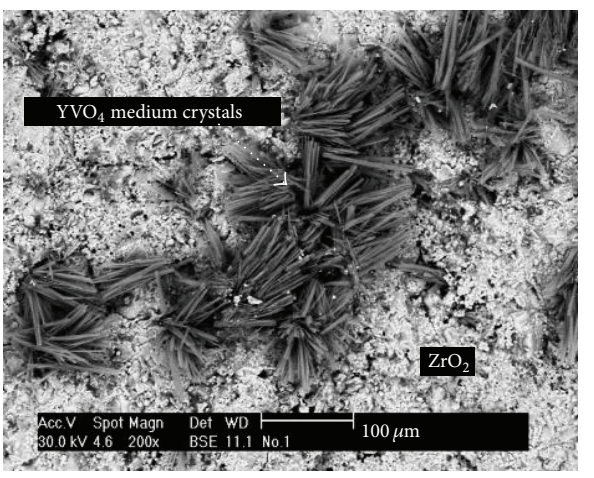

(c)

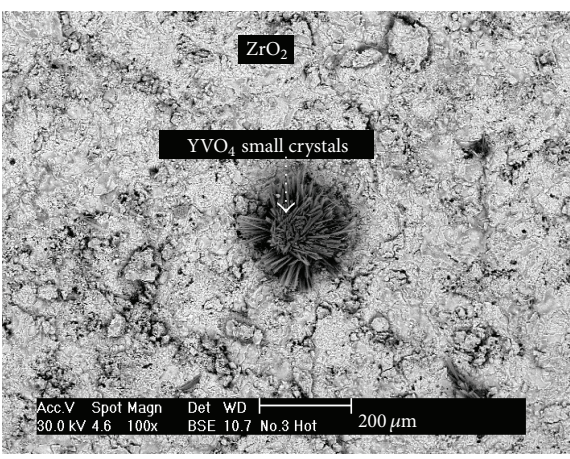

(e)

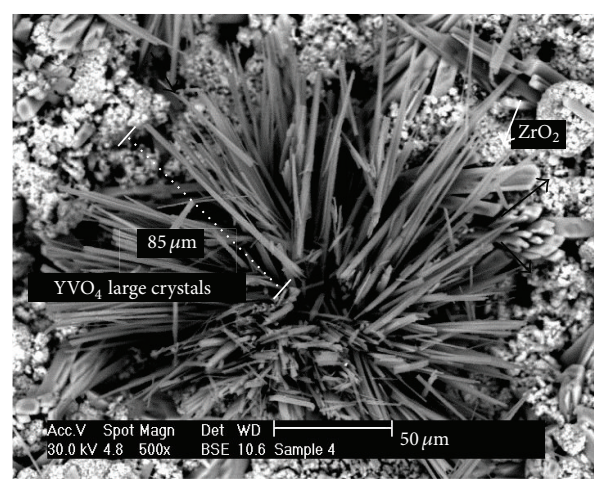

(b)

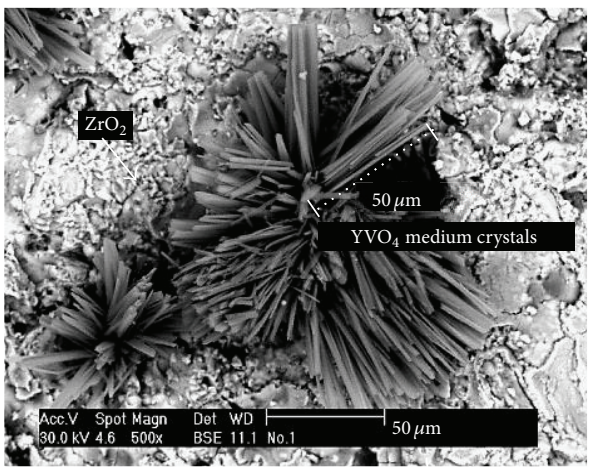

(d)

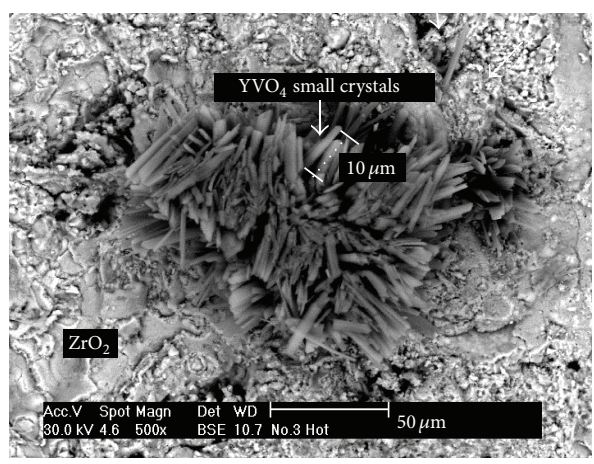

(f)

FIGURE 11: SEM micrographs of $\mathrm{YVO}_{4}$ crystals on the surface of YSZ coatings: (a, b) conventional YSZ; (c, d) YSZ as inner layer of YSZ/normal $\mathrm{Al}_{2} \mathrm{O}_{3}$ coating; and (e, f) $\mathrm{YSZ}$ as inner layer of $\mathrm{YSZ} /$ nano- $-\mathrm{Al}_{2} \mathrm{O}_{3}$ coating after hot corrosion testing.

$\mathrm{ZrO}_{2}$ at $1000^{\circ} \mathrm{C}$, and this phase will again be converted to monoclinic zirconia during normal cooling [22]. This phenomenon is accompanied by $3-5 \%$ local volume expansion and finally will cause the separation of YSZ top layer from the bond coat [10]. On the other hand, $\mathrm{Na}_{2} \mathrm{O}$ can react with $\mathrm{V}_{2} \mathrm{O}_{5}$ to directly produce $\mathrm{NaVO}_{3}$ (Reaction (4)):

$$
\mathrm{Na}_{2} \mathrm{O}(\mathrm{l})+\mathrm{V}_{2} \mathrm{O}_{5}(\mathrm{l}) \longrightarrow 2 \mathrm{NaVO}_{3}(\mathrm{l})
$$

Also, it had been reported that [10] $\mathrm{V}_{2} \mathrm{O}_{5}$ could react directly with $\mathrm{Y}_{2} \mathrm{O}_{3}$ (stabilizer component of zirconia) to form monoclinic $\mathrm{ZrO}_{2}$ and $\mathrm{YVO}_{4}$ crystals as hot corrosion products (Reaction (5)):

$$
\begin{aligned}
& \mathrm{ZrO}_{2}\left(\mathrm{Y}_{2} \mathrm{O}_{3}\right)(\mathrm{s})+\mathrm{V}_{2} \mathrm{O}_{5}(\mathrm{l}) \\
& \quad \longrightarrow \mathrm{ZrO}_{2} \text { (monoclinic) (s) }+2 \mathrm{YVO}_{4}(\mathrm{~s})
\end{aligned}
$$

The hot corrosion behavior of plasma sprayed $\mathrm{Al}_{2} \mathrm{O}_{3}$ and $\mathrm{ZrO}_{2}$ coatings in molten $\mathrm{Na}_{2} \mathrm{SO}_{4}$ has been investigated by Chen et al. [23]. Their research showed that $\mathrm{NaAlO}_{2}$ could be formed on the surface of $\mathrm{Al}_{2} \mathrm{O}_{3}$ particles (Reactions (6) and (7)) since the hot corrosion rate of $\mathrm{Al}_{2} \mathrm{O}_{3}$ coating in molten $\mathrm{Na}_{2} \mathrm{SO}_{4}$ was much lower in comparison to that of $\mathrm{ZrO}_{2}$ coating. In this research, $\mathrm{NaAlO}_{2}$ was barely detected by XRD analysis (see Figure 10), so it can be speculated that the $\mathrm{Al}_{2} \mathrm{O}_{3}$ layer could be protected by $\mathrm{NaAlO}_{2}$ compound during the primary cycles of hot corrosion test:

$$
\begin{gathered}
\mathrm{Na}_{2} \mathrm{SO}_{4}(\mathrm{l}) \longrightarrow \mathrm{Na}_{2} \mathrm{O}(\mathrm{l})+\mathrm{SO}_{3}(\mathrm{~g}) \\
\mathrm{Al}_{2} \mathrm{O}_{3}(\mathrm{~s})+\mathrm{Na}_{2} \mathrm{O}(\mathrm{l}) \longrightarrow 2 \mathrm{NaAlO}_{2}(\mathrm{~s})
\end{gathered}
$$

In some references $[24,25], \mathrm{Na}_{2} \mathrm{SO}_{4}$ has been known as an accelerator factor of chemical reactions during hot corrosion. 


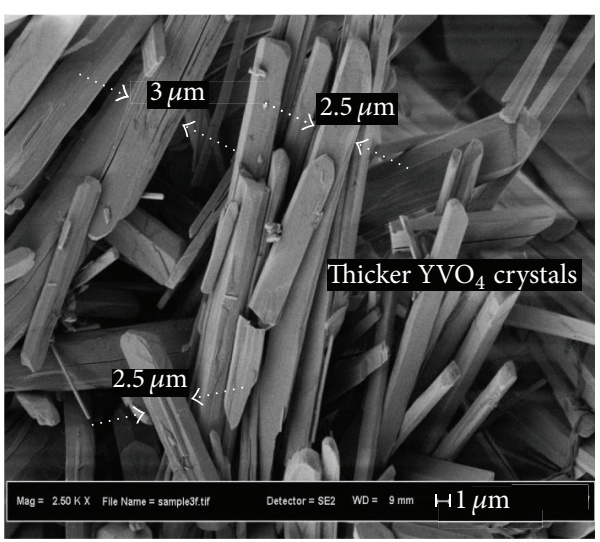

(a)

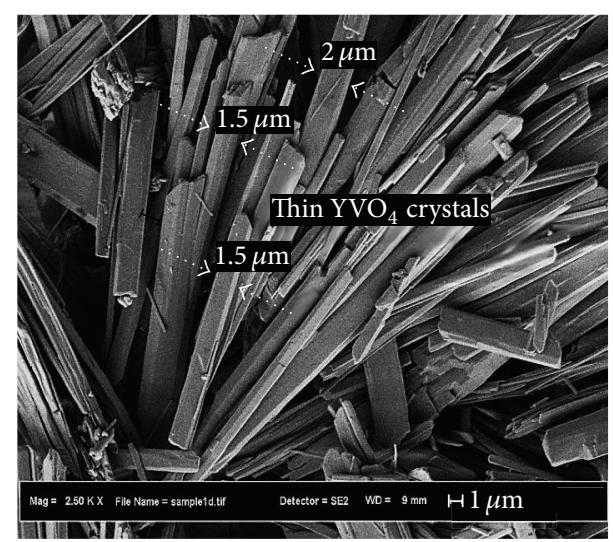

(b)

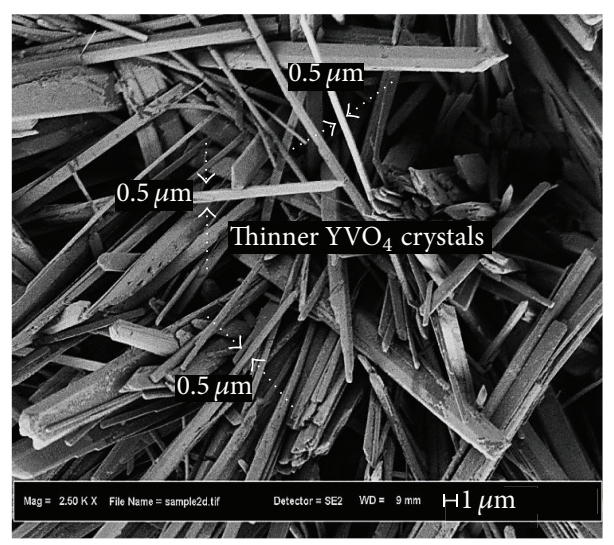

(c)

FIGURE 12: FESEM micrographs of $\mathrm{YVO}_{4}$ crystals on the surface of YSZ coatings: (a) thicker rod/flat crystals in conventional YSZ, (b) thin $\mathrm{rod} /$ flat crystals in YSZ as inner layer of YSZ/normal $\mathrm{Al}_{2} \mathrm{O}_{3}$ coating, and (c) thinner rod/flat or needle crystals in YSZ as inner layer of $\mathrm{YSZ} /$ nano- $\mathrm{Al}_{2} \mathrm{O}_{3}$ coating after hot corrosion testing.

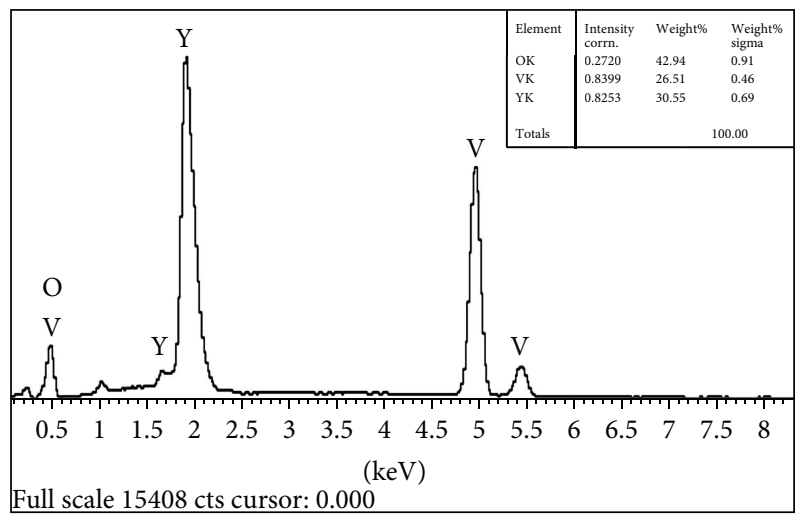

FIGURE 13: EDS spectrum from the rod/flat or needle crystals of $\mathrm{YVO}_{4}$ on the surface of YSZ layer of TBCs.

On the other hand, $\mathrm{NaVO}_{3}$ compound with relatively low melting point $\left(630^{\circ} \mathrm{C}\right)$ can considerably increase the phase transformation of tetragonal $\mathrm{ZrO}_{2}$ to monoclinic $\mathrm{ZrO}_{2}$ during hot corrosion due to stabilizer depletion $\left(\mathrm{Y}_{2} \mathrm{O}_{3}\right)$.

Ramachandra and other investigators reported that the reaction between the molten $\mathrm{Na}_{2} \mathrm{SO}_{4}$ and YSZ coating could not occur to any considerable extent, as the solidification of molten salt inside the porosities of ceramic coating and stress creation can be one of the main factors of degradation of YSZ coating during hot corrosion [4]. Hence, it can be concluded that the infiltration of molten corrosive materials into the YSZ layer can be a major deterioration mechanism of thermal barrier coatings during hot corrosion process.

It was reported that molten $\mathrm{NaVO}_{3}$ also increases the mobility of atoms, enhancing the depletion of $\mathrm{Y}_{2} \mathrm{O}_{3}$ from YSZ and the growth of $\mathrm{YVO}_{4}$ crystals $[22,24]$. On the other hand, the presence of high $\mathrm{V}$ concentration as seen on the coating surfaces tends to attract the $\mathrm{Y}^{3+}$ in the lattice of YSZ which has the mobility to migrate preferentially toward the reaction interface. It can be inferred that the percentage of hot corrosion products will be increased with increases in the reaction time (multiple hot corrosion cycles) which can finally extend the corroded regions. It can be supposed that the best nucleation locations for the formation of new heterogeneous $\mathrm{YVO}_{4}$ crystals are previously formed $\mathrm{YVO}_{4}$ crystals, as this case resembles the role of grain boundaries in the heterogeneous nucleation and growth process [16].

As mentioned previously, phase transformation of tetragonal zirconia to monoclinic zirconia is accompanied by local volume increase which generates compressive stresses. 

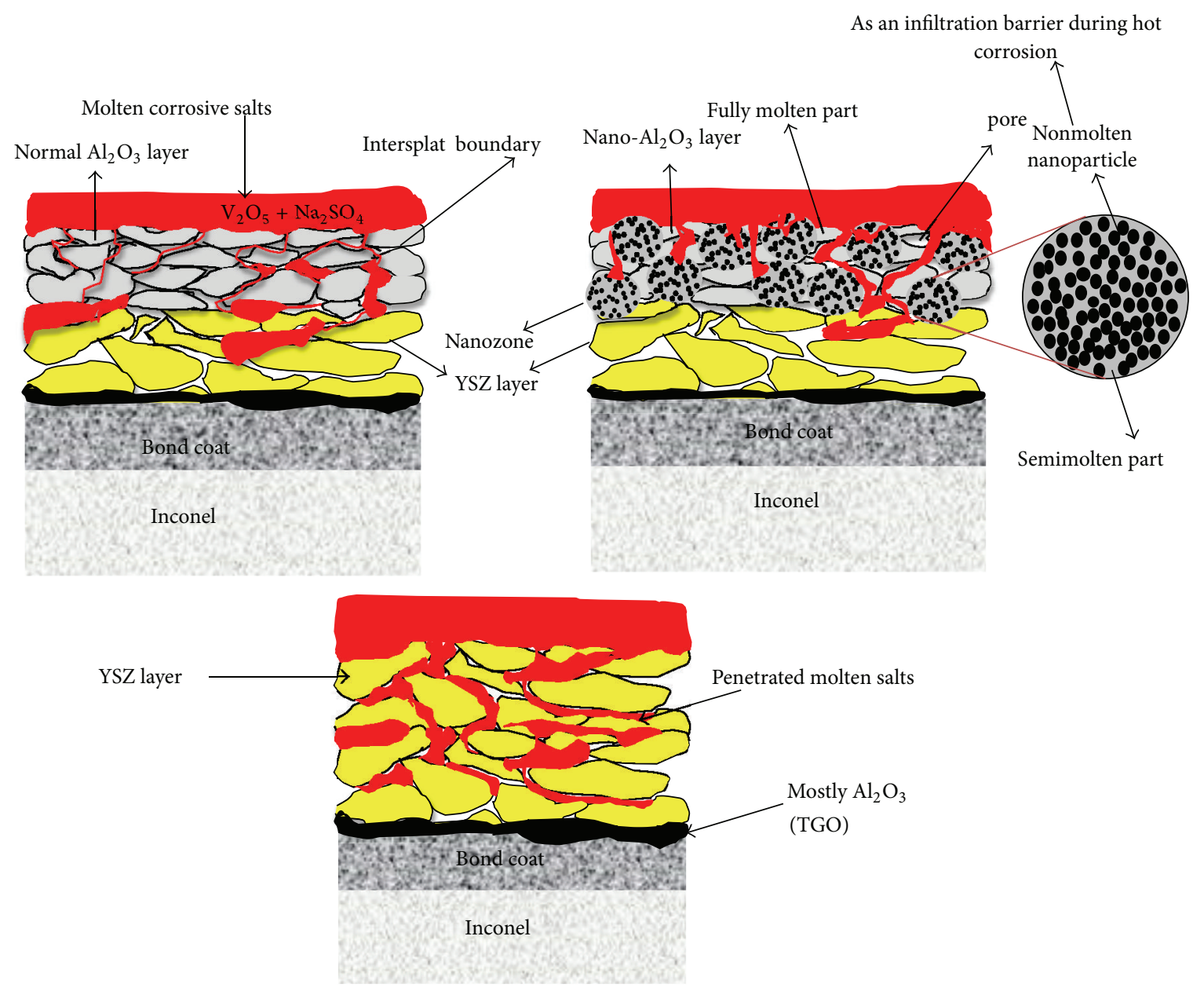

FIGURE 14: Schematic illustration of corrosive molten salts infiltration into the YSZ layer of different thermal barrier coating systems during hot corrosion process at elevated temperatures.

According to previous observation [10], $\mathrm{YVO}_{4}$ crystals could impose additional compressive stresses to the YSZ layer.

It can be said that inhomogeneities, pores, and microcracks play a principal role in the molten salts infiltration into the coating during hot corrosion (see Figure 14). It was found that nanostructured YSZ coatings including fully molten parts and nanozones are able to reduce oxygen and corrosive molten salts infiltration into the coating at elevated temperatures $[10,26]$.

In this research, dense nano- $\mathrm{Al}_{2} \mathrm{O}_{3}$ layer significantly prevented the diffusion of molten salts into the YSZ layer; therefore the amount of monoclinic $\mathrm{ZrO}_{2}$ and $\mathrm{YVO}_{4}$ crystals was substantially reduced in $\mathrm{YSZ} /$ nano- $-\mathrm{Al}_{2} \mathrm{O}_{3}$ coating in comparison with conventional YSZ and YSZ/normal $\mathrm{Al}_{2} \mathrm{O}_{3}$ coatings after hot corrosion test.

Formation of large rod/flat or needle-shaped $\mathrm{YVO}_{4}$ crystals with an average length of $85 \mu \mathrm{m}$ in conventional YSZ coating was observed. These crystals grow outward from the surface (see Figure 15) and cause additional stresses in the coating. The spallation of normal YSZ occurred at the NiCrAlY/YSZ interface (Figures 9(a) and 9(b)) due to those additional stresses in the coating.

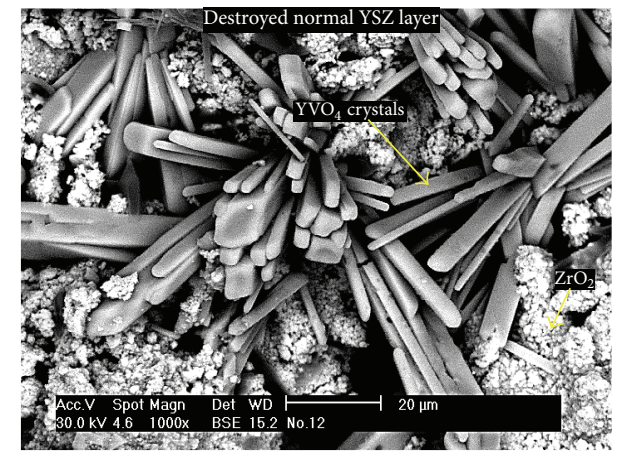

FIGURE 15: Outward growth of $\mathrm{YVO}_{4}$ crystals in conventional YSZ coating.

In other words, separation of normal YSZ coating from the bond coat is as a direct result of the formation of monoclinic $\mathrm{ZrO}_{2}$ and $\mathrm{YVO}_{4}$ large crystals (Figures 11(a) and 11(b)) in YSZ layer during hot corrosion. But in the YSZ/normal $\mathrm{Al}_{2} \mathrm{O}_{3}$ coating, a small amount of molten salts penetrated through the alumina layer towards the YSZ (Figures 11(c) and 14) and reacted with $\mathrm{Y}_{2} \mathrm{O}_{3}$ (stabilizer of $\mathrm{ZrO}_{2}$ ) at 
the $\mathrm{YSZ} /$ normal $\mathrm{Al}_{2} \mathrm{O}_{3}$ interface. Although monoclinic $\mathrm{ZrO}_{2}$ had been decreased to $21 \%$, the presence of $\mathrm{YVO}_{4}$ crystals on the YSZ as inner layer had a significant role in the spallation of normal $\mathrm{Al}_{2} \mathrm{O}_{3}$ coating from the YSZ layer, as the medium length of $\mathrm{YVO}_{4}$ crystals was about $50 \mu \mathrm{m}$. On the other hand, in the YSZ/nano- $\mathrm{Al}_{2} \mathrm{O}_{3}$ coating, the least amount of molten salts infiltrated through nanoalumina layer towards the YSZ layer and reacted with YSZ at the interface of $\mathrm{YSZ} /$ nano- $\mathrm{Al}_{2} \mathrm{O}_{3}$ (see Figure 14). In can be said that the $\mathrm{YVO}_{4}$ small crystals did not play a substantial role in the spallation of nano- $\mathrm{Al}_{2} \mathrm{O}_{3}$ layer from the YSZ because of the short length of $\mathrm{YVO}_{4}$ crystals, which was about $10 \mu \mathrm{m}$. However, the spallation of nano- $\mathrm{Al}_{2} \mathrm{O}_{3}$ layer is related to the formation of monoclinic $\mathrm{ZrO}_{2}$ (15\%) at the interface of $\mathrm{YSZ} /$ nano- $\mathrm{Al}_{2} \mathrm{O}_{3}$ coating during hot corrosion test. The aforementioned results show that YSZ/nano- $\mathrm{Al}_{2} \mathrm{O}_{3}$ coating has better corrosion behavior in comparison with other coatings at elevated temperatures.

\section{Conclusions}

(1) Generation of granulated (sprayable) nano- $\mathrm{Al}_{2} \mathrm{O}_{3}$ powders is followed by production of nanostructured $\mathrm{Al}_{2} \mathrm{O}_{3}$ layer over the YSZ coating using air plasma spraying method.

(2) Monoclinic $\mathrm{ZrO}_{2}$ and $\mathrm{YVO}_{4}$ crystals (as hot corrosion products) were generally formed on the YSZ layer during hot corrosion which are mainly related to the reaction of molten salts containing $\mathrm{Y}_{2} \mathrm{O}_{5}$ and $\mathrm{NaVO}_{3}$ with $\mathrm{Y}_{2} \mathrm{O}_{3}$ (stabilizer component of $\mathrm{ZrO}_{2}$ ). Hot corrosion products finally led to the spallation of the TBC from the bond coat.

(3) The average length and number of rod crystals of $\mathrm{YVO}_{4}$ in $\mathrm{YSZ}$ as the inner layer of $\mathrm{YSZ} /$ nano- $\mathrm{Al}_{2} \mathrm{O}_{3}$ coating had been substantially reduced in comparison to those of YSZ/normal $\mathrm{Al}_{2} \mathrm{O}_{3}$ and conventional YSZ coatings after hot corrosion test. On the other hand, the volume fraction of monoclinic zirconia in YSZ as inner layer of $\mathrm{YSZ} /$ nano- $-\mathrm{Al}_{2} \mathrm{O}_{3}$ coating was much lower compared to that of the other coatings.

(4) According to the aforementioned results, it can be concluded that the packness and homogeneity of nanostructured $\mathrm{Al}_{2} \mathrm{O}_{3}$ layer caused the reduction of hot corrosion products formation in the YSZ layer. In other words, the dense nanostructured $\mathrm{Al}_{2} \mathrm{O}_{3}$ layer with lower pinholes and microcracks significantly prevented the diffusion of molten salts into the YSZ layer; therefore the amount of monoclinic $\mathrm{ZrO}_{2}$ and $\mathrm{YVO}_{4}$ crystals weas substantially reduced at the $\mathrm{YSZ} /$ nano- $-\mathrm{Al}_{2} \mathrm{O}_{3}$ interface after $52 \mathrm{~h}$ of hot corrosion test compared to those of conventional YSZ and $\mathrm{YSZ} /$ normal $\mathrm{Al}_{2} \mathrm{O}_{3}$ coatings.

\section{Acknowledgments}

The work is financed by the Ministry of Higher Education of Malaysia and Research Management Center of UTM (postdoctoral part). The authors also would like to acknowledge the Ministry of Higher Education of Malaysia and Universiti Teknologi Malaysia (UTM) for providing research facilities and financial support under the Grant Q.J130000.252 $4.02 \mathrm{H} 55$.

\section{References}

[1] A. G. Evans, D. R. Mumm, J. W. Hutchinson, G. H. Meier, and F. S. Pettit, "Mechanisms controlling the durability of thermal barrier coatings," Progress in Materials Science, vol. 46, no. 5, pp. 505-553, 2001.

[2] W. Brandi, H. J. Grabke, D. Toma, and J. Krüger, "The oxidation behaviour of sprayed MCrAlY coatings," Surface and Coatings Technology, vol. 86-87, no. 1, pp. 41-47, 1996.

[3] X. H. Zhong, Y. M. Wang, Z. H. Xu, Y. F. Zhang, J. F. Zhang, and X. Q. Cao, "Hot-corrosion behaviors of overlay-clad yttriastabilized zirconia coatings in contact with vanadate-sulfate salts," Journal of the European Ceramic Society, vol. 30, no. 6, pp. 1401-1408, 2010.

[4] C. Ramachandra, K. N. Lee, and S. N. Tewari, "Durability of TBCs with a surface environmental barrier layer under thermal cycling in air and in molten salt," Surface and Coatings Technology, vol. 172, no. 2-3, pp. 150-157, 2003.

[5] M. Saremi, A. Afrasiabi, and A. Kobayashi, "Bond coat oxidation and hot corrosion behavior of plasma sprayed YSZ coting on Ni superalloy," Journal of Transaction of JWRI, vol. 36, pp. 41-45, 2007.

[6] D. Munz and T. Fett, Mechanical Properties, Failure Behavior, Materials Selection, Springer, Berlin, Germany, 1999, 9:10.

[7] Y. N. Wu, P. L. Ke, Q. M. Wang, C. Sun, and F. H. Wang, "High temperature properties of thermal barrier coatings obtained by detonation spraying," Corrosion Science, vol. 46, no. 12, pp. 2925-2935, 2004.

[8] L. L. Shaw, D. Goberman, R. Ren et al., "The dependency of microstructure and properties of nanostructured coatings on plasma spray conditions," Surface and Coatings Technology, vol. 130 , no. 1 , pp. 1-8, 2000.

[9] A. C. Fox and T. W. Clyne, "Oxygen transport by gas permeation through the zirconia layer in plasma sprayed thermal barrier coatings," Surface and Coatings Technology, vol. 184, no. 2-3, pp. 311-321, 2004.

[10] M. Saremi, A. Keyvani, and M. H. Sohi, "Hot corrosion resistance and mechanical behavior of atmospheric plasma sprayed conventional and nanostructured zirconia coatings," International Journal of Modern Physics, vol. 5, pp. 720-727, 2012.

[11] Y. Qian, L. Du, and W. Zhang, "Preparation of spherical $\mathrm{Y}_{2} \mathrm{SiO}_{5}$ powders for thermal-spray coating," Particuology, vol. 7, no. 5, pp. 368-372, 2009.

[12] E. Garcia, J. Mesquita-Guimarães, P. Miranzo et al., "Mullite and mullite $/ \mathrm{ZrO}_{2}-7 \mathrm{wt} . \% \mathrm{Y}_{2} \mathrm{O}_{3}$ powders for thermal spraying of environmental barrier coatings," Journal of Thermal Spray Technology, vol. 19, no. 1-2, pp. 286-293, 2010.

[13] L. Marcinauskas, "Deposition of alumina coatings from nanopowders by plasma spraying," Journal of Materials Science (MEDŽIAGOTYRA), vol. 16, pp. 47-51, 2010.

[14] X. Lin, Y. Zeng, S. W. Lee, and C. Ding, "Characterization of alumina-3 wt.\% titania coating prepared by plasma spraying of nanostructured powders," Journal of the European Ceramic Society, vol. 24, no. 4, pp. 627-634, 2004. 
[15] R. Ahmadi-Pidani, R. Shoja-Razavi, R. Mozafarinia, and H. Jamali, "Evaluation of hot corrosion behavior of plasma sprayed ceria and yttria stabilized zirconia thermal barrier coatings in the presence of $\mathrm{Na}_{2} \mathrm{SO}_{2}+\mathrm{V}_{2} \mathrm{O}_{2}$ molten salt," Ceramics Internationals, vol. 38, pp. 6613-6620, 2012.

[16] M. H. Habibi, L. Wang, and S. M. Guo, "Evolution of hot corrosion resistance of $\mathrm{YSZ}, \mathrm{Gd}_{2} \mathrm{Zr}_{2} \mathrm{O}_{7}$, and $\mathrm{Gd}_{2} \mathrm{Zr}_{2} \mathrm{O}_{7}+\mathrm{YSZ}$ composite thermal barrier coatings in $\mathrm{Na}_{2} \mathrm{SO}_{4}+\mathrm{V}_{2} \mathrm{O}_{5}$ at $1050^{\circ} \mathrm{C}$," Journal of the European Ceramic Society, vol. 32, no. 8, pp. 16351642, 2012.

[17] M. Daroonparvar, M. A. Mat Yajid, N. M. Yusof, and M. S. Hussain, "Formation of a dense and continues $\mathrm{Al}_{2} \mathrm{O}_{3}$ layer in nano thermal barrier coating systems for suppression of the spinels growth on the $\mathrm{Al}_{2} \mathrm{O}_{3}$ oxide scale during oxidation," Journal of Alloys and Compounds, vol. 571, pp. 205-220, 2013.

[18] M. Daroonparvar, M. A. Mat Yajid, N. M. Yusof et al., "Improvement of thermally grown oxide layer in thermal barrier coating systems with nano alumina as a third layer," Transactions of Nonferrous Metals Society of China, vol. 23, pp. 1322-1333, 2013.

[19] Q. L. Ge, T. C. Lei, J. F. Mao, and Y. Zhou, "In situ transmission electron microscopy observations of the tetragonal-tomonoclinic phase transformation of zirconia in $\mathrm{Al}_{2} \mathrm{O}_{3}-\mathrm{ZrO}_{2}(2$ mol \% $\mathrm{Y}_{2} \mathrm{O}_{3}$ ) composite," Journal of Materials Science Letters, vol. 12, no. 11, pp. 819-822, 1993.

[20] J. R. Brandon and R. Taylor, "Phase stability of zirconia-based thermal barrier coatings part II. Zirconia-ceria alloys," Surface and Coatings Technology, vol. 46, no. 1, pp. 91-101, 1991.

[21] H. C. Chen, Z. Y. Liu, and Y. C. Chuang, "Degradation of plasma-sprayed alumina and zirconia coatings on stainless steel during thermal cycling and hot corrosion," Journal of Thin solid Films, vol. 223, no. 1, pp. 56-64, 1993.

[22] S. V. Joshi and M. P. Srivastava, "On the thermal cycling life of plasma-sprayed yttria-stabilized zirconia coatings," Surface and Coatings Technology, vol. 56, no. 3, pp. 215-224, 1993.

[23] Z. Chen, N. Q. Wu, J. Singh, and S. X. Mao, "Effect of $\mathrm{Al}_{2} \mathrm{O}_{3}$ overlay on hot-corrosion behavior of yttria-stabilized zirconia coating in molten sulfate-vanadate salt," Thin Solid Films, vol. 443, no. 1-2, pp. 46-52, 2003.

[24] S. Y. Park, J. H. Kim, M. C. Kim, H. S. Song, and C. G. Park, "Microscopic observation of degradation behavior in yttria and ceria stabilized zirconia thermal barrier coatings under hot corrosion," Surface and Coatings Technology, vol. 190, no. 2-3, pp. 357-365, 2005.

[25] R. L. Jones, "Some aspects of the hot corrosion of thermal barrier coatings," Journal of Thermal Spray Technology, vol. 6, no. 1, pp. 77-84, 1997.

[26] M. Daroonparvar, M. A. Mat Yajid, N. M. Yusof, and M. S. Hussain, "Improved thermally grown oxide scale in air plasma sprayed NiCrAlY/Nano-YSZ coatings," Journal of Nanomaterials, vol. 2013, Article ID 520104, 9 pages, 2013. 

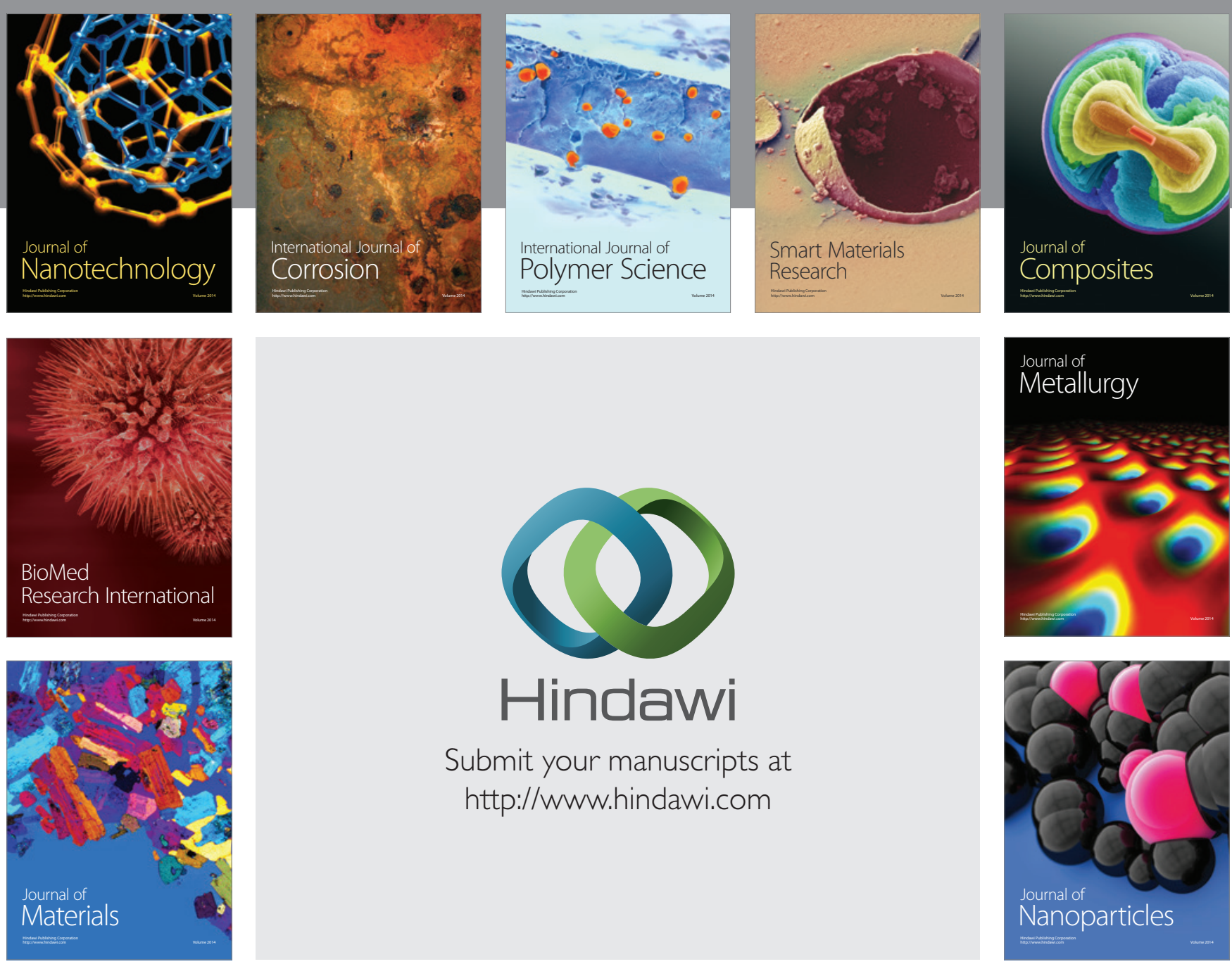

Submit your manuscripts at http://www.hindawi.com
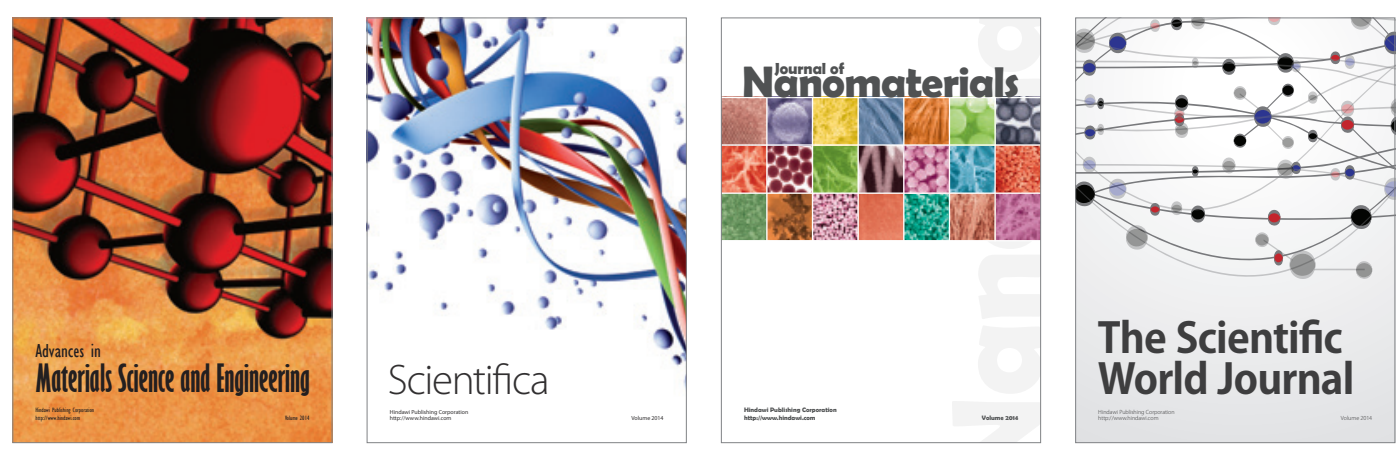

\section{The Scientific World Journal}
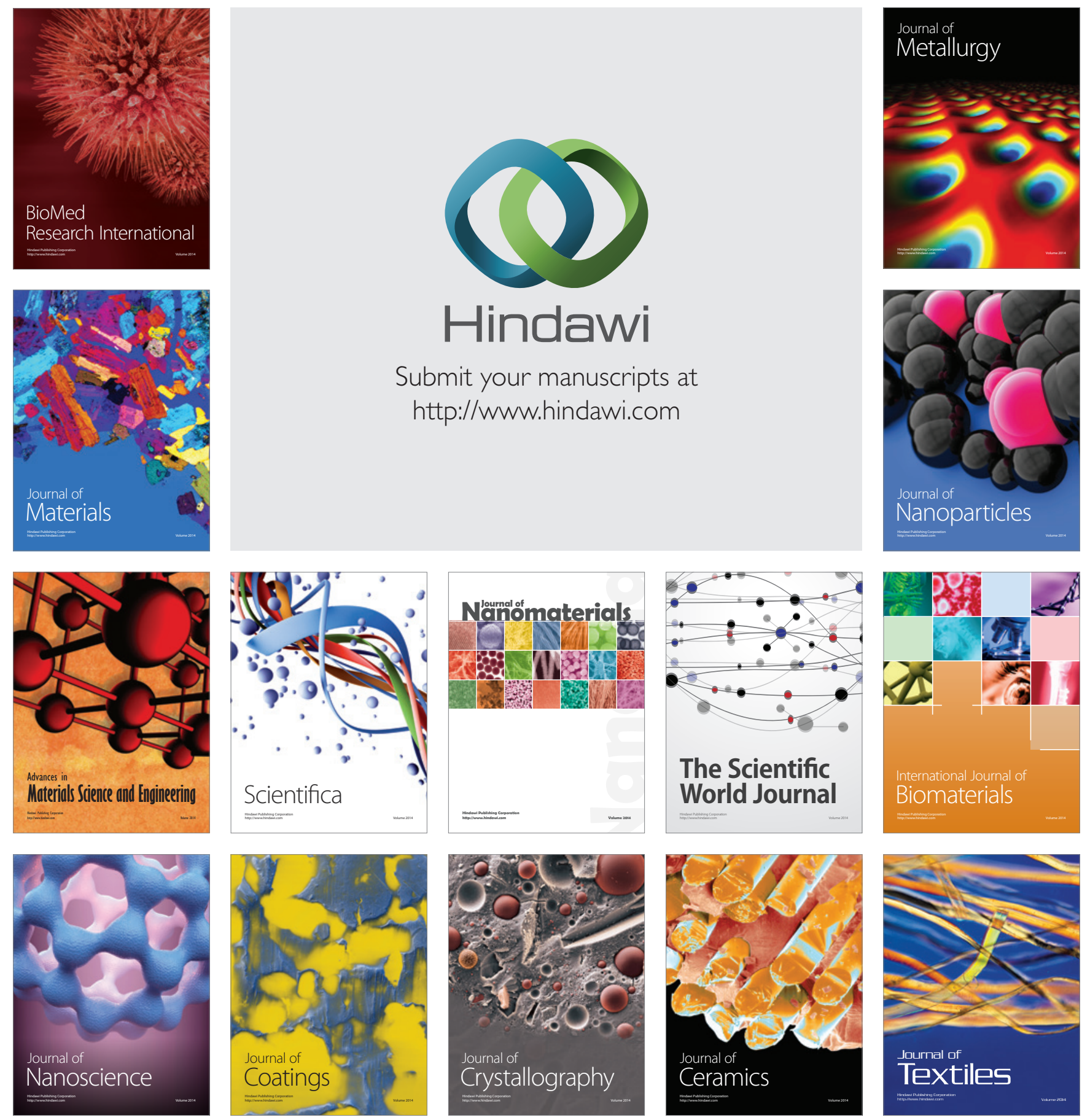